Nama : Maria Febri Puji Hartanti

Email : mfph.febri@gmail.com

\title{
Long-term Care Based on Journal of Aging and Health
}

Berdasarkan Jurnal of Aging and Health pelaksanaan prinsip-prinsip layanan kesehatan bagi lansia di wilayah Surabaya dan Malang tergolong kurang. Yang dimaksudkan kurang disini adalah banyak dari mereka yaitu masyarakat Kota Surabaya dan Kota Malang merasakan bahwa pelayanan yang disediakan oleh negara kurang memuaskan dan tergatorikan mahal untuk mereka. Tidak memuasakan bagi mereka artinya mereka tidak merasakan pelayanan tersebut sebanding dengan harga berobat untuk sembuh. Peran keluarga untuk menjaga kesehatan lansia juga kurang. Banyak dari anak cucu mereka pergi merantau kemudian berkeluarga dan lupa bahwa mereka memiliki seorang orang tua yang harus dijaga dan diawaso dalam kesehariannya. Dalam jurnal tersebut juga terdapat sebuah riset yang menunjukkan dari jutaan populasi di wilayah tersebut hanya memiliki ribuan tempat untuk berobat ( puskesmas, posyandu, pustu ). Yang mana menurut saya penyediaan fasilitas tersebut kurang.

Jika dibandingkan dengan negara tetangga yaitu Jepang, pola hidup yang dilakukan jauh berbeda dengan masyarkat Indonesia. Lansia di negara jepang mampu menunda munculnya penyakit hingga usia 75 tahun. Rahasia sehat dan panjang umur tersebut adalah konsumsi ikan laut yang baik untuk kesehatan jantung dan makanan fermentasi yang baik untuk kesehatan usus. Bahkan, masyarakat di Okinawa, Jepang, banyak yang hidup lebih dari 100 tahun karena memiliki pola makan yang luar biasa sehat.

Berbeda dengan masyarakat Indonesia terlebih lagi untuk kaum muda yang sangat menyukai makanan cepat saji dan menganggap bahwa merokok adalah hal yang keren dilakukan pada usianya tanpa memikirkan dampak saat mereka tua nantinya.

Dalam masa pandemik COVID-19 ini jika dilihat memang mempengaruhi semua elemen. Terutama rumah sakit yang menjadi tempat berkumpul dan sembuhnya banyak penyakit. Saya telah melakukan wawancara kepada seorang nenek 
yang tinggal bersama anak ke-2 nya di Malang. Nenek tersebut bernama Karijati berusia 85 tahun, pendidikan terakhir yang ditempuh adalah SR ( Sekolah Rakyat ). Nenek Karijati ini bisa di sebut nenek yang sehat di usianya karena tidak memiliki masalah penyakit dalam dirinya seperti jantung atau diabetes. Hal tersebut terjadi karena nenek Karijati ini melakukan kontrol kesehatan diri setiap bulannya, namun dia mengaku bahwa dia mengkonsumsi banyak obat"an. Dari hasil wawancara tentang bagaimana pelayanan yang di dapatkan selama dia berobat ini nenek Karijati berkata sampai saat ini pelayanan kesehatan yang ia dapatkan sangat memuaskan dan baik. Pelayanan tersebut ia rasakan sangat baik karena ia mendapat banyak perhatian dari anak-anaknya dan memiliki hidup yang berkecukupan. Dan hal tersebut sesuai dan memenuhi prinsip-prinsip yang dibahas dalam artikel Pratono \& Maharani (2018).

\section{DAFTAR PUSTAKA}

Pratono, A.H. \& Maharani, A. (2018). Long-term care in Indonesia: The role of integrated service post for elderly. Journal of Aging and Health, 30(10) 1556-1573 